\title{
Metabolism and biomass vertical distribution of zooplankton in the Bransfield Strait during the austral summer of $\mathbf{2 0 0 0}$
}

\author{
Lidia Yebra, ${ }^{1,2}$ Santiago Hernández-León, ${ }^{2}$ Carlos Almeida ${ }^{2}$ \& Pierrick Bécognée ${ }^{2}$ \\ 1 Institut de Ciències del Mar, CSIC, Passeig Marítim de la Barceloneta 37-49, ES-08003 Barcelona, Spain \\ 2 Biological Oceanography Laboratory, Facultad de Ciencias del Mar, Universidad de Las Palmas de Gran Canaria, Campus Universitario de Tafira, \\ ES-35017 Las Palmas de Gran Canaria, Canary Islands, Spain
}

\author{
Keywords \\ AARS; Antarctic Peninsula; biomass; ETS; \\ metabolism; zooplankton.

\section{Correspondence \\ Lidia Yebra, Institut de Ciències del Mar, CSIC, Passeig Maritim de la Barceloneta 37-49, ES-08003 Barcelona, Spain. E-mail: lyebra@icm.csic.es}

doi:10.1111/j.1751-8369.2009.00116.x

\begin{abstract}
The vertical distribution $(0-550 \mathrm{~m})$ of zooplankton biomass, and indices of respiration (electron transfer system [ETS]) and structural growth (aminoacyltRNA synthetases activity [AARS]), were studied in waters off the Antarctic Peninsula during the austral summer of 2000. The dominant species were the copepod Metridia gerlachei and the euphausiid Euphausia superba. We observed a vertical krill/copepod substitution in the water column. The zooplankton biomass in the layer at a depth of 200-500 $\mathrm{m}$ was of the same magnitude as the biomass in the layer at a depth of 0-200 $\mathrm{m}$, indicating that biomass in the mesopelagic zone is an important fraction of the total zooplankton in Antarctic waters. The metabolic rates of the zooplankton community were sustained by less than $0.5 \%$ of the primary production in the area, suggesting that microplankton or small copepods are the main food source. Neither food availability nor predation seemed to control mesozooplankton biomass. The wide time lag between the abundance peak of the dominant copepod ( $M$. gerlachei) and the phytoplankton bloom is suggested to be the main explanation for the low summer zooplankton biomass observed in these waters.
\end{abstract}

The Bransfield Strait is located between the South Shetland Islands and the Antarctic Peninsula. It presents high variability in both physical conditions (e.g., mesoscale eddies and fronts; Zhou et al. 2006) and primary production rates (Basterretxea \& Arístegui 1999; Varela et al. 2002; Morán et al. 2006). It is also considered to be a highly productive region for all trophic levels (Huntley et al. 1990; Zhou et al. 1994). The studies of Antarctic zooplankton have focused on estimating the impact of these organisms on the development and evolution of primary production in areas affected by strong micro- or mesoscale plankton distribution patterns, or by the influence of eddies and frontal systems, which are characteristic features of the Southern Ocean. More recently, the influence of the physical environment on zooplankton species distribution, as well as their role in energy flow, has been studied using indices of physiological processes (Bergeron et al. 1985; Schalk 1990; Drits et al. 1993; Hernández-León et al. 1999; Hernández-León et al. 2000). However, not all the variability in zooplankton biomass is explained by physical changes.
Zooplankton biomass and abundance in the Bransfield Strait have been studied during the austral spring and summer seasons (Alcaraz et al. 1998; Hernández-León et al. 1999; Hernández-León et al. 2000; Cabal et al. 2002; Calbet et al. 2005), showing a great interannual variability. Previous studies (Hernández-León et al. 1999; Hernández-León et al. 2000; Calbet et al. 2005) have reported low mesozooplankton biomass around the Antarctic Peninsula. This is probably related to predation and/or food quality, rather than to food availability. Hernández-León et al. (2000) studied the distribution of mesozooplankton biomass and metabolism in the upper 200-m layer, showing low zooplankton biomass with a rather high growth rate. Yet, zooplankton consumed less than $10 \%$ of the primary production, and a top-down effect of krill on copepods in the area was suggested. In addition, an important fraction of the biomass in these waters was found in the mesopelagic zone (below 200-m depth), as was observed in previous works on Antarctic copepods (Lancraft et al. 1989; Lancraft et al. 1991; Lopez \& Huntley 1995; Pakhomov et al. 1996; Lancraft et al. 
2004) and euphausiids (Hernández-León, PortilloHahnefeld et al. 2001; Hernández-León \& Montero 2006). However, most studies to date have been focused on the upper 200-m layer. The study of biomass and diel vertical migration of the deep-water mesozooplankton (200-550-m depth) could improve our understanding of the trophic web in this region of the Southern Ocean.

The main aim of this study is to give a first insight on zooplankton biomass and metabolic rates in relation to the vertical distribution over the 0-550-m water column. We used two enzymatic methods to obtain highresolution estimates of respiration and growth at depth. The activity of the electron transfer system (ETS; Packard 1971) was used to assess the maximum potential respiration. The aminoacyl-tRNA synthetases activity (AARS; Yebra \& Hernández-León 2004) was applied as an index of the in-situ growth rate. The combined use of these methods allowed us to simultaneously study in-situ respiration and growth rates of mixed zooplankton populations inhabiting mesopelagic depths, without the need for incubation or elaborate procedures. A recent discussion of the usefulness and advantages of these biochemical methods can be found in Båmstedt (2000),
Ikeda et al. (2000), Hernández-León, Almeida et al. (2001, 2002), Yebra, Harris et al. (2005), Yebra et al. (2006) and Guerra (2006). Secondarily, we seek to investigate the importance of bottom-up and top-down controls on zooplankton biomass in the Bransfield Strait. Finally, despite the short austral summer nights, we studied the plankton dynamic in the water column by day and night in an attempt to look at diel vertical migration and carbon fluxes mediated by zooplankton in the region.

\section{Methods}

\section{Sampling}

During the austral summer of 2000, from 24 January to 17 February, 10 stations were sampled on board the RV BIO Hespérides in the Bransfield Strait, Antarctic Peninsula (Fig. 1), using a Longhurst-Hardy Plankton Recorder (LHPR; 200- $\mu \mathrm{m}$ mesh net). The average day length was $20 \mathrm{~h}$ (06.00-02.00 h GMT), and darkness lasted for only 4 h (02.00-06.00 h GMT). Eight hauls were carried out by day (14.33-24.21 h GMT) and two hauls were carried out at night (03.56-04.39 h GMT), in order to study diel

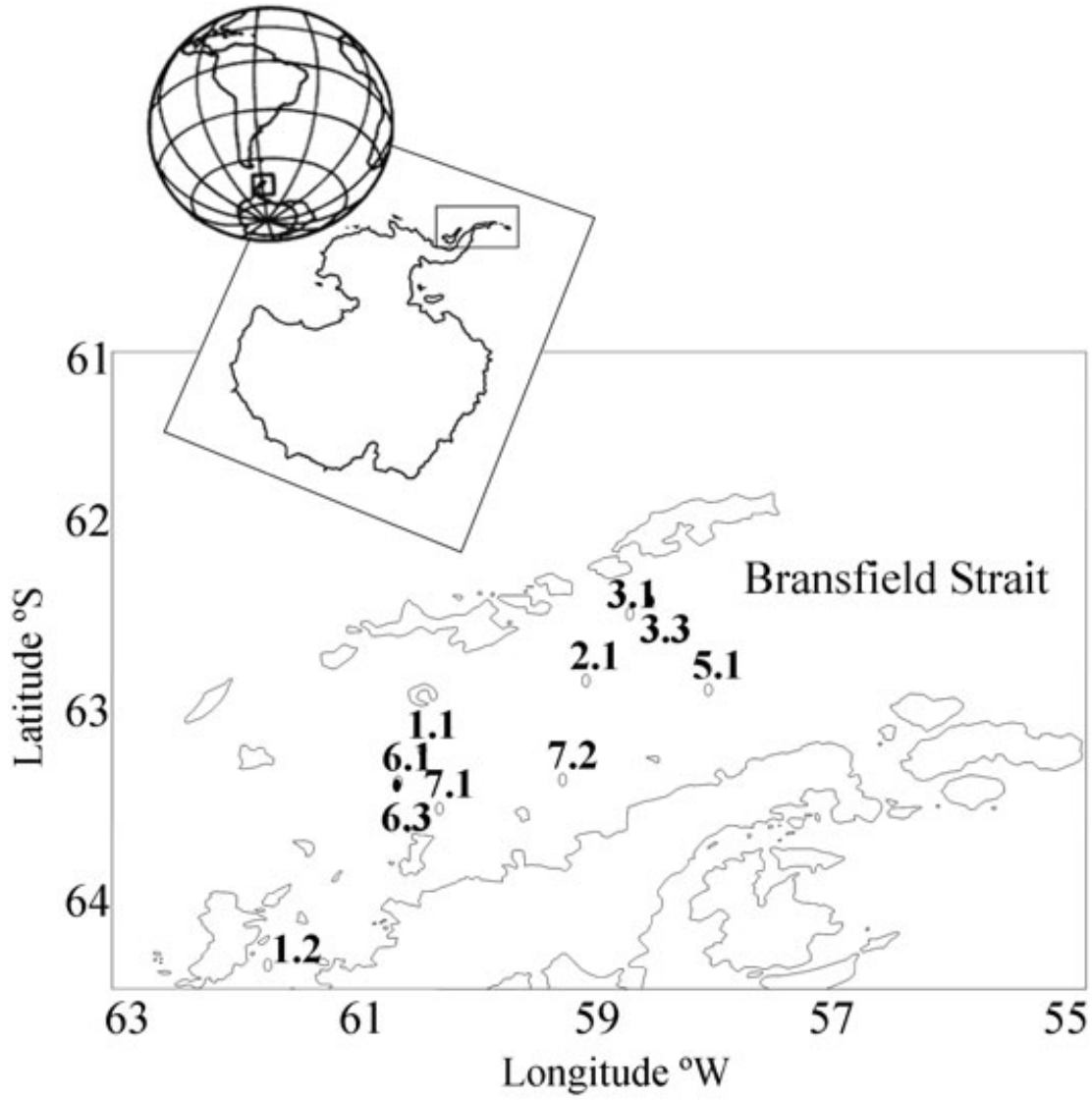

Fig. 1 Location of the Longhurst-Hardy Plankton Recorder net stations: $\bigcirc$, day; $\bullet$, night. 
differences in biomass and metabolic profiles. Samples were collected from 550 to $0 \mathrm{~m}$, at a speed of 3-4 knots. Each haul contained about 22 samples, corresponding to different layers, ranging from 13- to 24-m deep. A conductivity-temperature-depth (CTD) recorder was used to obtain high-resolution profiles of temperature, conductivity and fluorescence. On board, samples were split into two halves. One half was stored in liquid nitrogen at $-196^{\circ} \mathrm{C}$, for biochemical assays, and the other half was preserved in $4 \%$ formalin for presence/absence analyses of the two main groups found: euphausiids and copepods.

\section{Biomass and metabolic rates}

Frozen samples were homogenized with Tris-HCl buffer $(\mathrm{pH}=7.8)$ before the assays. The protein content was measured using the folin dye method (Lowry et al. 1951), as modified for microanalysis by Rutter (1967). We transformed biomass, measured as protein content, to carbon, using published ratios: protein : dry weight $(\mathrm{dw})=0.192$; carbon : dry weight $=0.40$ (Postel et al. 2000).

The ETS activity was assayed using the method of Packard (1971), as modified by Gómez et al. (1996). ETS activity was corrected for the in-situ temperature at each depth using the Arrhenius equation with an activation energy of $15 \mathrm{kcal} \mathrm{mol}^{-1}$, as given by Packard et al. (1975). AARS activity was measured using the method of Yebra \& Hernández-León (2004), and was corrected for the in-situ temperature with an activation energy of $10.5 \mathrm{kcal} \mathrm{mol}^{-1}$ (Guerra 2006).

The community respiration rates $\left(\mathrm{R} ; \mathrm{mg} \mathrm{C} \mathrm{m}^{-2} \mathrm{~h}^{-1}\right)$ were assessed from specific ETS activities $\left(\mu \mathrm{O}_{2} \mathrm{mg}\right.$ $\operatorname{prot}^{-1} \mathrm{~h}^{-1}$ ) and integrated biomass $\left(\mathrm{mg}\right.$ protein $\left.\mathrm{m}^{-2}\right)$, assuming a respiratory quotient of 0.97 (Omori \& Ikeda 1984) and a theoretical R : ETS ratio of 0.5 (HernándezLeón \& Gómez 1996; Ikeda et al. 2000). The community growth rates $\left(\mathrm{nm} \mathrm{PPi} \mathrm{m} \mathrm{m}^{-2} \mathrm{~h}^{-1}\right)$ were calculated from specific AARS activities (nm PPi mg protein ${ }^{-1} \mathrm{~h}^{-1}$ ) and integrated biomass ( $\mathrm{mg}$ protein $\mathrm{m}^{-2}$ ). We assessed the community potential ingestion ( $\mathrm{I} ; \mathrm{mg} \mathrm{C} \mathrm{m}^{-2} \mathrm{~h}^{-1}$ ) from respiration rates $(\mathrm{R})$, assuming an assimilation and a gross growth efficiency of 70 and $30 \%$, respectively, and applying the equation proposed by Ikeda \& Motoda (1978): $\mathrm{I}=100 \mathrm{R} /(70-30)=2.5 \mathrm{R}$.

\section{Active flux}

Protein content and ETS activity data were averaged at 25-m intervals to obtain day and night vertical distribution profiles. The biomass night profile was then subtracted from the biomass day profile to show daily changes. The day-minus-night protein profile was inte- grated to estimate migrant biomass $\left(\mathrm{mg}\right.$ protein $\mathrm{m}^{-2}$ ). The negative area values represent the migrant biomass that reached the euphotic layer at night (0-245-m depth).

To assess the respiratory flux $\left(\mu \mathrm{O}_{2} \mathrm{~m}^{-2}\right.$ day $\left.^{-1}\right)$ of carbon to deep waters, positive values of the ETS $\left(\mu \mathrm{l} \mathrm{O}_{2} \mathrm{~m}^{-3} \mathrm{~h}^{-1}\right)$ day-minus-night profile were integrated and divided by the integrated biomass present in the same depth range (as in Yebra, Almeida et al. 2005). The specific ETS activity measured at depth $\left(\mu \mathrm{l} \mathrm{O}_{2} \mathrm{mg}\right.$ protein $^{-1} \mathrm{~h}^{-1}$ ) was then multiplied by the migrant biomass $\left(\mathrm{mg}\right.$ protein $\left.\mathrm{m}^{-2}\right)$ to obtain the flux resulting from migrants' respiration located below 200-m depth during the day. For all calculations, we applied $4 \mathrm{~h}$ of darkness per day, and an R : ETS ratio of 0.5 (see above).

\section{Results}

\section{Hydrology}

We found no sea-ice cover during the sampling period. The water temperature ranged between 1 and $2^{\circ} \mathrm{C}$ at the surface, decreasing to $-1^{\circ} \mathrm{C}$ at 500-m depth (Fig. 2). We observed occasional deep warm water masses at a depth of $200 \mathrm{~m}$. Salinity ranged from 33.9 to 34.4 at the surface, but was similar below $100 \mathrm{~m}$ at all stations. The maximum of chlorophyll was observed at around 25-m depth, where values reached up to $14 \mathrm{mg}$ Chl. $a \mathrm{~m}^{-3}$.

\section{Zooplankton biomass}

The most abundant organisms were the pelagic copepod Metridia gerlachei and the euphausiid Euphausia superba. Calanoides acutus and Calanus propinquus were also present, but were found only in low numbers. Visual assessments of the presence/absence of copepods and euphausiids showed that by day large euphausiids were in the surface waters (above 250-m depth), whereas smaller juveniles stayed at depth (500-550 m). M. gerlachei was located in a compact layer from 300 to $500 \mathrm{~m}$ depth. Occasional layers of salps (Salpa thompsonii) were also found around 100- and 300-m depths (Fig. 3a). Surprisingly, the biomass values by day were similar in both the 0-200-m and the 200-550-m layers $(t=-0.17$, $p=0.86$; Table 1). At night, euphausiids were observed above $100 \mathrm{~m}$ and below $400 \mathrm{~m}$, whereas copepods dominated the layer in between (150-400 m), and salps scarcely occurred above $100 \mathrm{~m}$ (Fig. 3b). During the night, the biomass was concentrated in the upper 200-m layer, increasing by twofold compared with daytime values $(t=2.85, p<0.01$; Table 1$)$.

\section{Metabolic indices}

During the day, specific ETS activities decreased slightly from the surface down to $200 \mathrm{~m}$, but presented higher 
Temperature

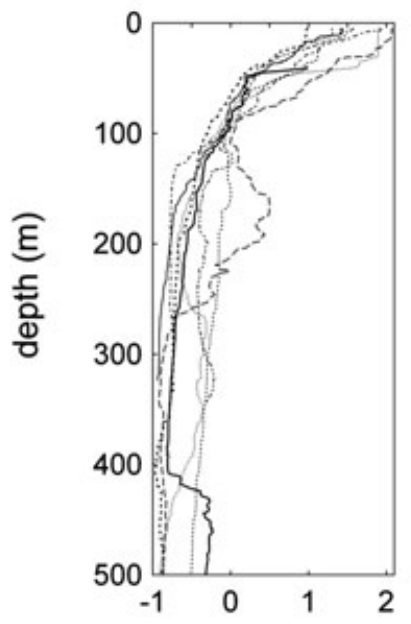

Salinity

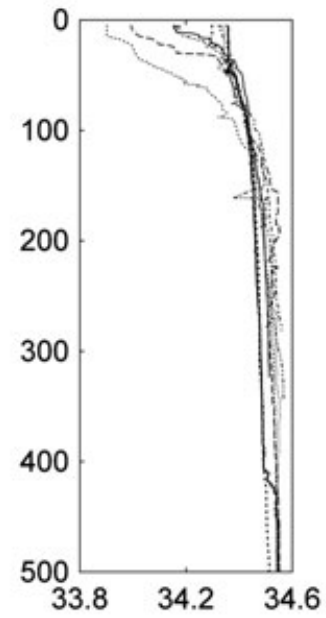

Chlorophyll a

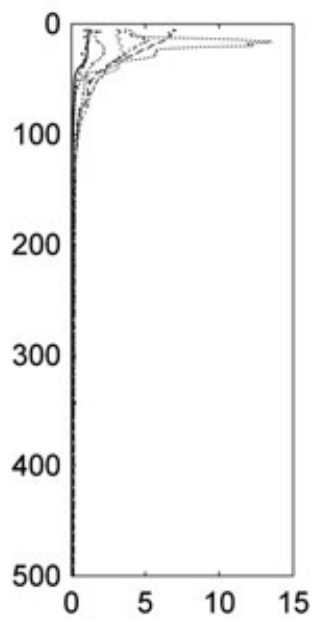

Fig. 2 Daytime conductivity-temperature-depth (CTD) vertical profiles of temperature $\left({ }^{\circ} \mathrm{C}\right)$, salinity and chlorophyll $a\left(\mathrm{mg}\right.$ Chl. $a$ m $\left.{ }^{-3}\right)$.

values at mesopelagic depths (200-550 m, $t=-2.81$, $p<0.01$; Fig. 3a). In contrast, specific AARS activities were higher above $200 \mathrm{~m}$ (Fig. 3a), with an averaged specific AARS activity double that in the 200-550-m layer $(t=3.83, p<0.001$; Table 1$)$.

At night, the specific ETS remained variable, with peaks at 25- and 225-m depths. Specific AARS activity peaks were also higher in the upper 250-m layer (Fig. 3b). The upward diel migration was accompanied by a $60 \%$ increase in averaged specific ETS activity in the upper $200 \mathrm{~m}(t=-2.78, p<0.01)$, and a slight but not significant $(t=0.93, p=0.35) 15 \%$ decrease between 200 and $550 \mathrm{~m}$. The specific AARS activity remained constant in shallow waters $(t=0.42, p=0.67)$ and increased, although not significantly $(t=-1.77, p=0.079)$, by $46 \%$ in the mesopelagic zone at night (Table 1).

\section{Community rates and active flux}

Considering the whole water column, we observed a small increase in specific ETS and AARS activities by night (13\% and 9\%, respectively; Table 1). However, as the biomass also increased at night, the respiration rate of the community was 1.7 times higher during the night $\left(0.20 \mathrm{mg} \mathrm{C} \mathrm{m}^{-2} \mathrm{~h}^{-1}\right)$ compared to daytime $\left(0.12 \mathrm{mg} \mathrm{C} \mathrm{m}^{-2} \mathrm{~h}^{-1}\right)$. The community growth rate was also $50 \%$ higher by night (360.6 $\mathrm{nm} \mathrm{PPi} \mathrm{m}^{-2} \mathrm{~h}^{-1}$ ) than by day $\left(241.8 \mathrm{~nm} \mathrm{PPi} \mathrm{m}^{-2} \mathrm{~h}^{-1}\right)$. The mean community respiration (over $0-550 \mathrm{~m}$ ) was $1.74 \mathrm{mg} \mathrm{C} \mathrm{m}^{-2}$ day $^{-1}$, and the community ingestion $(0-550 \mathrm{~m})$ assessed from respiration was $4.35 \mathrm{mg} \mathrm{C} \mathrm{m}^{-2}$ day $^{-1}$.

From the day-minus-night biomass differences observed in the upper $250 \mathrm{~m}$ (Fig. 4a) we obtained a daily migrant biomass of $92.3 \mathrm{mg}$ protein $\mathrm{m}^{-2}$. The integrated total ETS activity diel difference (Fig. 4b) was $187.8 \mu \mathrm{l} \mathrm{O}_{2} \mathrm{~m}^{-2} \mathrm{~h}^{-1}$, and we estimated an active flux to deep waters of $10.2 \mu \mathrm{g} \mathrm{C} \mathrm{m}^{-2} \mathrm{~d}^{-1}$.

\section{Discussion}

\section{Relationship between biomass vertical distribution and enzyme activities}

The Antarctic Peninsula is a region of low zooplankton biomass in comparison with other Antarctic areas (Atkinson et al. 1997; Ward et al. 1997; Ward et al. 2004). The summer zooplankton biomass in the Bransfield Strait has high interannual variability, ranging from 35 up to $1039 \mathrm{mg} \mathrm{C} \mathrm{m}^{-2}$ (Table 2). The highest biomass record corresponds to a summer when the salp $S$. thompsonii was the most abundant zooplankton species (Alcaraz et al. 1998). This species can have a widespread oceanic distribution further north and east of the study area (Hosie 1994). However, they were scarcely found during our study, and were mainly associated with relatively warmer waters. Instead, zooplankton was dominated by crustaceans, and the biomass values we observed were within the lower range of the previous values reported in the area (Table 2).

The patterns of zooplankton vertical distribution described for Antarctic waters coincide with our observations in the Bransfield Strait. These studies show a surface layer dominated by krill, and a wide layer of smaller organisms below 200-m depth (Pakhomov et al. 1994; Murray et al. 1995; Weeks et al. 1995; Hernández-León, Portillo-Hahnefeld et al. 2001). During our sampling, 
(a) Day

Biomass

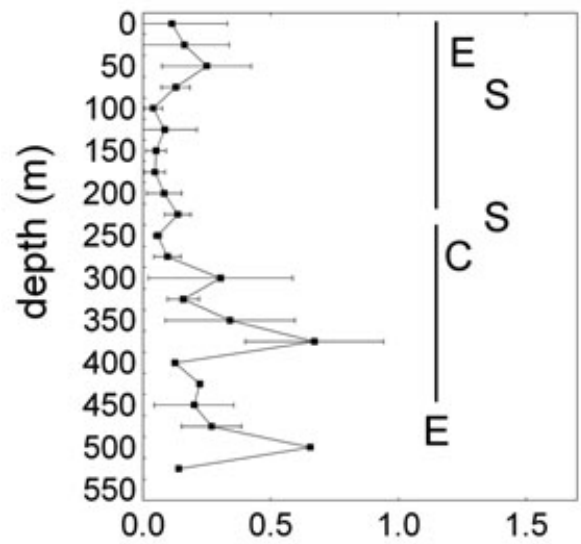

specific ETS

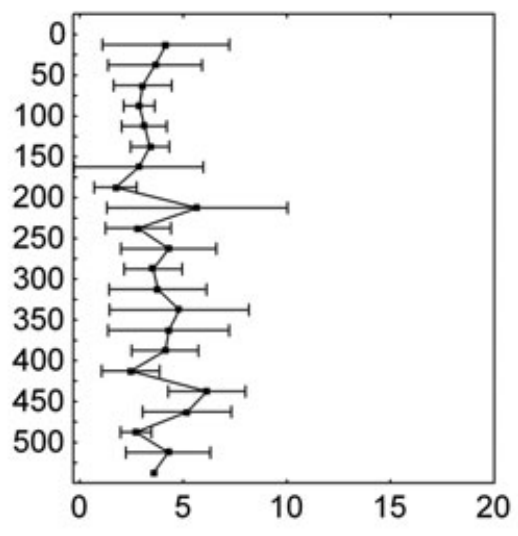

specific AARS

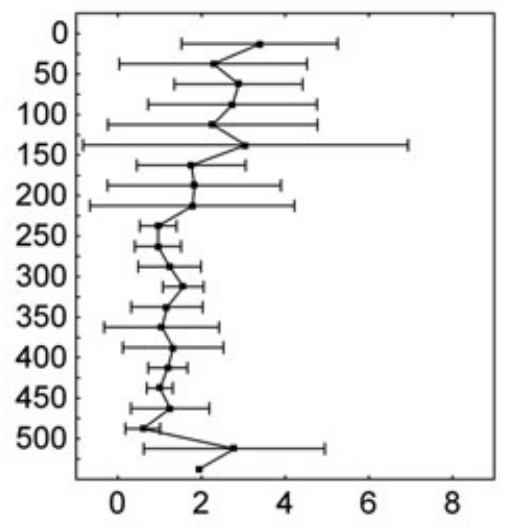

(b) Night

Biomass

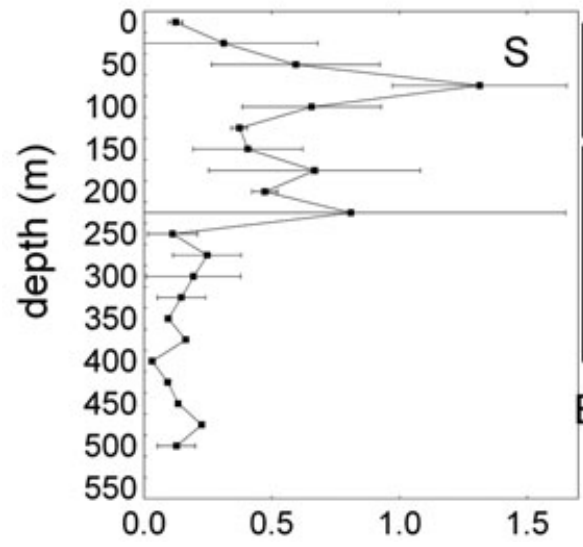

specific ETS

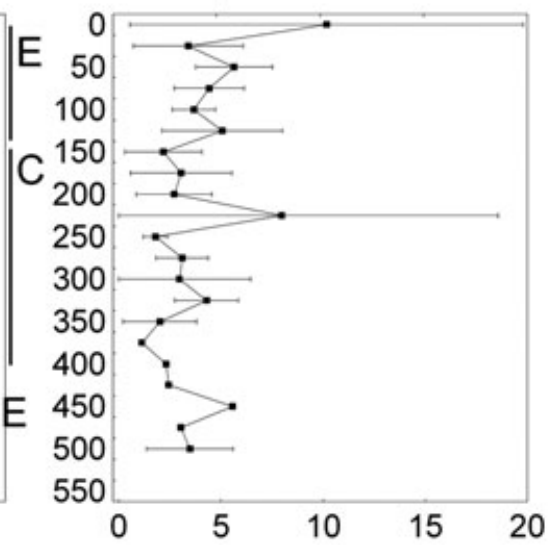

specific AARS

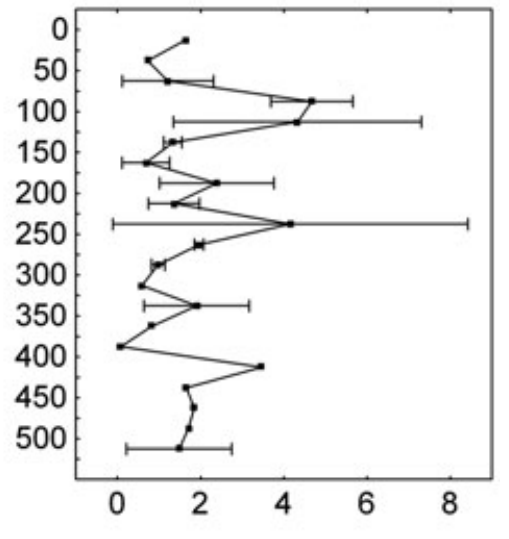

Fig. 3 (a) Day and (b) night averaged vertical profiles ( \pm SD) of biomass (mg protein $\mathrm{m}^{-3}$ ), specific electron transfer system (ETS) activity $\left(\mu \mathrm{O} \mathrm{O}_{2} \mathrm{mg}\right.$ protein ${ }^{-1} \mathrm{~h}^{-1}$ ) and specific aminoacyl-tRNA synthetases (AARS) activity ( $\mathrm{nm}$ PPi mg protein ${ }^{-1} \mathrm{~h}^{-1}$ ). Biomass plots show the general vertical distribution of euphausiids (E), copepods (C) and salps (S).

euphausiids (E. superba) were concentrated above $200 \mathrm{~m}$ and around 550-m depth. The copepod M. gerlachei was found in the 300-500-m layer, as previously observed (Schnack-Schiel \& Mújica 1994; Lopez \& Huntley 1995; Hernández-León, Portillo-Hahnefeld et al. 2001), and was the dominant copepod species during our sampling. This agrees with Pakhomov et al. (2000), who observed that this copepod could make up 40-95\% of the total abundance in the absence of krill swarms. Despite the reduced krill presence below 200-m depth, the biomass in the mesopelagic zone was similar to that in upper waters. This is in agreement with studies showing that copepods could represent more than $50 \%$ of the total biomass in Antarctic waters (Boysen-Ennen et al. 1991; Conover \& Huntley 1991; Pakhomov et al. 2000).

The vertical distribution of ETS activities was related to biomass concentrations. The highest specific respiration rates (ETS activities) were found below $200 \mathrm{~m}$, and were mainly related to copepod populations. Because of the inverse allometric relationship between size and metabolism (Ikeda 1985), copepods would show a higher metabolism than euphausiids, thereby explaining the observed tendency of specific respiration rates to increase with depth. Specific ETS activity increases in relation to high biomass values were previously observed in the Weddell Sea (Jacques \& Panouse 1991; Schnack-Shiel \& Mújica 1994). The night-time increase in biomass from 0 to $200 \mathrm{~m}$ also corresponded to higher values of specific ETS, and suggests that higher ingestion rates occur at night. Enhanced feeding at night has been previously observed in Antarctic waters. Atkinson et al. (1996) observed higher grazing rates of copepods, and Hernández-León, Portillo-Hahnefeld et al. (2001) found higher gut fullness of Antarctic krill at night. Opposite to 
Table 1 Zooplankton biomass (mg protein $\mathrm{m}^{-3}$, except where otherwise noted), specific electron transfer system (ETS; $\mu \mathrm{l} \mathrm{O}_{2} \mathrm{mg} \mathrm{protein}^{-1} \mathrm{~h}^{-1}$ ) and

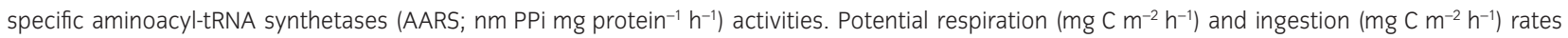
calculated from specific ETS activities and biomass. Growth rates ( $\mathrm{nm} \mathrm{PPi} \mathrm{m}^{-2} \mathrm{~h}^{-1}$ ) calculated from specific AARS activities and biomass (see Methods) for depths of 0-200, 200-550 and 0-550 $\mathrm{m}$ in the Bransfield Strait.

\begin{tabular}{|c|c|c|c|c|c|}
\hline & \multirow{2}{*}{$\begin{array}{l}\text { Depth range } \\
\text { (m) }\end{array}$} & \multicolumn{2}{|l|}{ Day } & \multicolumn{2}{|l|}{ Night } \\
\hline & & Mean \pm SD (number of samples) & Range & Mean \pm SD (number of samples) & Range \\
\hline \multirow[t]{2}{*}{ Biomass } & $0-200$ & $0.23 \pm 0.61(62)$ & $0.001-4.68$ & $0.54 \pm 0.39(21)$ & $0.05-1.56$ \\
\hline & $200-550$ & $0.24 \pm 0.20(59)$ & $0.004-0.86$ & $0.25 \pm 0.32(28)$ & $0.03-1.71$ \\
\hline Average & $0-550$ & $0.24 \pm 0.46(121)$ & & $0.37 \pm 0.38(49)$ & \\
\hline Total & $0-550$ & $0.52 / 130.0 *(121)$ & & $1.23 / 179.4^{\star}(49)$ & \\
\hline \multirow[t]{2}{*}{ Specific ETS } & 0-200 & $3.12 \pm 2.03(76)$ & $0.04-10.86$ & $4.99 \pm 4.21(21)$ & $1.05-21.19$ \\
\hline & $200-550$ & $4.23 \pm 2.69(83)$ & $0.54-14.18$ & $3.63 \pm 3.63(28)$ & $0.51-20.10$ \\
\hline Average & $0-550$ & $3.70 \pm 2.45(159)$ & & $4.20 \pm 3.90(49)$ & \\
\hline \multirow[t]{2}{*}{ Specific AARS } & 0-200 & $2.49 \pm 2.28(62)$ & $0.11-11.36$ & $2.23 \pm 2.00(18)$ & $0.03-7.33$ \\
\hline & $200-550$ & $1.26 \pm 1.70(65)$ & $0.08-7.87$ & $1.84 \pm 1.83(24)$ & $0.07-9.28$ \\
\hline Average & $0-550$ & $1.86 \pm 1.90(127)$ & & $2.01 \pm 1.89(42)$ & \\
\hline \multirow[t]{2}{*}{ Potential respiration } & 0-200 & 0.037 & & 0.140 & \\
\hline & $200-550$ & 0.092 & & 0.083 & \\
\hline Average & $0-550$ & $0.065 \pm 0.039$ & & $0.111 \pm 0.041$ & \\
\hline \multirow[t]{2}{*}{ Potential ingestion } & $0-200$ & 0.093 & & 0.350 & \\
\hline & $200-550$ & 0.231 & & 0.206 & \\
\hline Average & 0-550 & $0.162 \pm 0.197$ & & $0.278 \pm 0.102$ & \\
\hline \multirow[t]{2}{*}{ Growth } & $0-200$ & 114.54 & & 240.84 & \\
\hline & $200-550$ & 105.84 & & 161.00 & \\
\hline Average & 0-550 & $110.19 \pm 6.15$ & & $200.92 \pm 56.46$ & \\
\hline
\end{tabular}

* $\mathrm{mg}$ protein $\mathrm{m}^{-2}$.

respiration, the specific growth rates (AARS activity) during the day in the upper $200 \mathrm{~m}$ were higher than in the mesopelagic layer. This indicates higher specific growth rates in the euphotic zone, where primary production was concentrated. Also, specific AARS activities did not increase at night, which suggests that although feeding seemed to have a day-night cycle, the somatic growth of the populations remained constant in the upper waters.

\section{Control of zooplankton biomass}

One of the main unsolved questions in the region is which factors determine the low summer zooplankton biomass. We looked at zooplankton metabolic rates and food availability to discuss the importance of the bottom-up and top-down control of zooplankton populations. The community respiration in the 0-200-m layer (1.33 $\mathrm{mg} \mathrm{C} \mathrm{m}^{-2}$ day $^{-1}$ ) was similar to the summer 1993 estimates in the Bransfield Strait $\left(1.5 \mathrm{mg} \mathrm{C} \mathrm{m}^{-2}\right.$ day $^{-1}$; Hernández-León et al. 2000). However, in summer 1994, the biomass was dominated by salps, and the zooplankton carbon losses due to respiration ranged from 10 to $50 \mathrm{mg} \mathrm{C} \mathrm{m}^{-2}$ day $^{-1}$ (Alcaraz et al. 1998). On the other hand, we found that respiration in the mesopelagic waters (200-550-m depth) was 30\% higher than that in the euphotic zone $\left(2.2 \mathrm{mg} \mathrm{C} \mathrm{m}^{-2} \mathrm{day}^{-1}\right)$. When comparing the average respiration rate of the whole 0-550-m water column (1.74 $\mathrm{mg} \mathrm{C} \mathrm{m}^{-2}$ day $^{-1}$ ) with the average primary production found in the area (2854.5 $\mathrm{mg} \mathrm{C} \mathrm{m}^{-2}$ day $^{-1}$; Agawin et al. unpubl. data; Table 2), we observe that the zooplankton daily respiration needs accounted for only $0.06 \%$ of phytoplankton production. This value is much lower than the 0.9 and $5.3 \%$ reported for crustacean zooplankton and salps, respectively, by Alcaraz et al. (1998). Likewise, the average community ingestion $(0-550 \mathrm{~m})$ derived from respiration represented only $0.15 \%$ of the primary production. Therefore, in our study, zooplankton metabolic requirements accounted for less than $0.3 \%$ of the photosynthetic production. This percentage is lower than that observed in previous studies (Atkinson \& Shreeve 1995; Lopez \& Huntley 1995; Alcaraz et al. 1998; HernándezLeón et al. 1999; Hernández-León et al. 2000). However, it is important to note that the phytoplankton bloom in February 2000 was notably intense. The average chlorophyll a concentration varied from $3.16 \pm 1.5 \mathrm{mg}$ Chl. $a \mathrm{~m}^{-3}$ (ranging from 0.38 to $16.75 \mathrm{mg}$ Chl. $a \mathrm{~m}^{-3}$ ) in open water (Agustí et al. 2004) to $19 \pm 5 \mathrm{mg}$ Chl. $a \mathrm{~m}^{-3}$ within the waters of Deception Island (Sturz et al. 2003). Also, the primary production rate was the highest recorded in the area that we know of (Table 2). The other important food source to consider for 
(a) Biomass day minus night

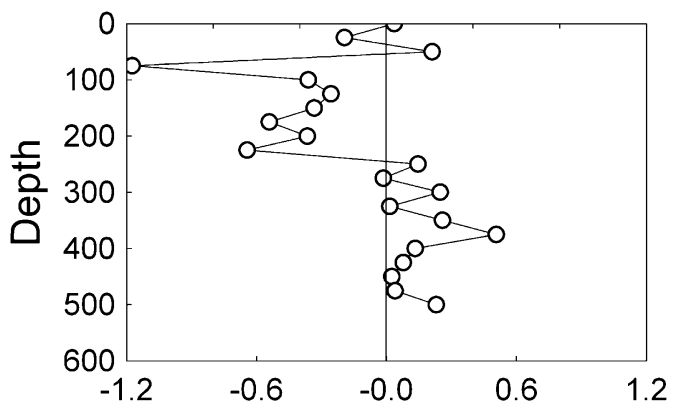

(b) Total ETS day minus night

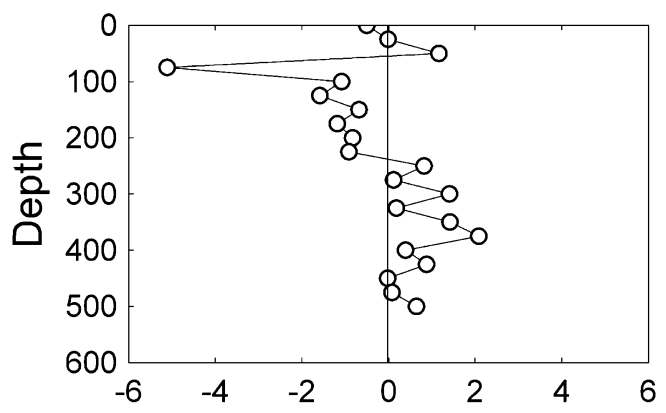

Fig. 4 Day-minus-night averaged value profiles of (a) biomass ( $\mathrm{mg}$ protein $\mathrm{m}^{-3}$ ) and (b) total electron transfer system activity (ETS; $\mu\left(\mathrm{O}_{2} \mathrm{~m}^{-3} \mathrm{~h}^{-1}\right)$.

mesozooplankton is microplankton. E. superba is known to feed on ciliates as well as copepods (Price et al. 1988; Froneman et al. 1996; Atkinson \& Snyder 1997; Perissinotto et al. 2000; Wickham \& Berninger 2007). Likewise, M. gerlachei has shown preference for ciliates and other copepods over algae, in both austral autumn and winter (Atkinson 1996, 1998; Pasternak \& Schnack-Schiel 2001; Wickham \& Berninger 2007). Calbet et al. (2005) suggested that, in this region, the mesozooplankton was grazing on microplankton rather than on phytoplankton, and was therefore aiding the development of the phytoplankton bloom. Nevertheless, the net microplankton production found $\left(76.36 \mathrm{mg} \mathrm{C} \mathrm{m}^{-3}\right.$ day $^{-1}$; Agustí et al. 2004) was much higher than the phytoplankton production (4.6 $\mathrm{mg} \mathrm{C} \mathrm{m}^{-3} \mathrm{day}^{-1}$; Agawin, unpubl. data), although it was similar to the value found in a previous study in the region $\left(93.35 \mathrm{mg} \mathrm{C} \mathrm{m}^{-3}\right.$ day $^{-1}$; Arístegui et al. 1996). Therefore, the mesozooplankton metabolism during summer 2000 was not limited by phyto- or microplankton availability. Hence, as previously suggested (Hernández-León et al. 1999), we reject the bottom-up control hypothesis.
On the other hand, a top-down effect of krill on copepods has been suggested as the main factor controlling copepod abundance and development in the Bransfield Strait (Hernández-León et al. 1999; Hernández-León et al. 2000; Hernández-León, Portillo-Hahnefeld et al. 2001). This idea is supported by the inverse relationship of krill/non-krill zooplankton distribution observed here, and in other Antarctic areas, where high krill densities coincide with very low copepod abundances (Hosie 1994; Voronina et al. 1994; Atkinson et al. 1999). As mentioned above, krill is able to prey selectively on copepods (Price et al. 1988; Graneli et al. 1993; Atkinson \& Snyder 1997), although their impact on copepods might be reduced in spring or summer, when phytoplankton concentrations are high. Hernández-León, Portillo-Hahnefeld et al. (2001) observed that during the austral summer of 1993 E. superba grazed on phytoplankton by day, but, despite the high primary production (Basterretxea $\&$ Arístegui 1999; Table 2), they switched to feed on M. gerlachei at night, when copepods migrated upwards. Our study reflected a similar scenario, with zooplankton biomass in the lower range and a high primary production. Hence, the low biomass found could be the result of predation pressure (top-down control). However, as a result of the short length of the summer night and the high phytoplankton concentrations available to krill during the bloom, their impact on copepods would be minimal. Thus, predation might not be the only cause for the low zooplankton biomass in the Bransfield Strait, and copepod life history might be an important factor to explain the low values found in summer. Ward et al. (2004) suggested that the low biomass found was probably linked to the higher latitude, lower temperatures and reduced production in comparison with areas further north. This combination could delay the development of zooplankton populations. This agrees with studies of $M$. gerlachei showing that their abundance peaks in autumn, i.e., March-May (Schnack-Schiel \& Hagen 1994, 1995; Tucker $\&$ Burton 1990) or in early winter, i.e., June (King \& LaCasella 2003). King \& LaCasella (2003) found the biomass of $M$. gerlachei in the waters of Deception Island (Bransfield Strait) to be $1.7 \mathrm{mg} \mathrm{dw} \mathrm{m}^{-3}$ during February 2000, which is similar to the biomass that we observed in open waters at that time $\left(1.2 \mathrm{mg} \mathrm{dw} \mathrm{m}^{-3}\right)$. Nevertheless, the biomass they found in June $\left(31.4 \mathrm{mg} \mathrm{dw} \mathrm{m}^{-3}\right.$ ) was 20 times greater, showing a four-month lag response of the copepod population to the phytoplankton bloom. This may be explained by their preference for microplankton and small copepods (i.e., Oithona spp.) as prey, the populations of which would peak after the phytoplankton bloom. Therefore, it is probable that the low zooplankton biomass found in summer is not caused by predation pressure either, but instead is the result of life-cycle 


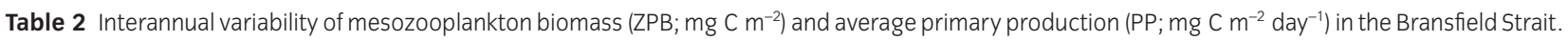

\begin{tabular}{|c|c|c|c|c|c|}
\hline Depth & Date & ZPB & Reference & PP & Reference \\
\hline 0-200 & $12 / 1991$ & $34.6^{*}$ & Hernández-León et al. 1999 & 333 & Basterretxea \& Arístegui 1999 \\
\hline $0-200$ & 01/1993-02/1993 & $133.6^{*}$ & Hernández-León et al. 2000 & $423-3913$ & Basterretxea \& Arístegui 1999 \\
\hline $0-200$ & $01 / 1994$ & 713-1039 & Alcaraz et al. 1998 & 684-1396 & Alcaraz et al. 1998 \\
\hline $0-200$ & 12/1995-02/1996 & $136-431$ & Cabal et al. 2002 & $14-176$ & Varela et al. 2002 \\
\hline $0-43$ & $02 / 1998$ & - & - & $262-889$ & Morán et al. 2001 \\
\hline 0-200 & $01 / 2000-02 / 2000$ & $94.0-240.5$ & Present work & $578-6911$ & Agawin unpubl. data \\
\hline $0-550$ & & $270.4-373.2$ & & & \\
\hline $0-200$ & $01 / 2001-02 / 2001$ & $9.3-179.3^{*}$ & Catalán et al. 2008 & - & - \\
\hline $0-250$ & $12 / 2002$ & 55 & Calbet et al. 2005 & $23-451^{\dagger}$ & Morán et al. 2006 \\
\hline
\end{tabular}

*Carbon calculated from dry weight (dw) applying a C : dw ratio of 0.4 for crustaceans (Postel et al. 2000) and 0.05 for salps (Schneider 1989).

tPP estimated from surface experiments, and assuming $15 \mathrm{~h}$ of light per day.

adaptation of the dominant copepod species to the production dynamics in the region.

\section{Vertical migration and carbon fluxes}

Biomass in the upper 200-m layer increased by twofold at night, corresponding to the upward migration of M. gerlachei (Park \& Wormuth 1993; Lopez \& Huntley 1995; Hernández-León, Portillo-Hahnefeld et al. 2001; King \& LaCasella 2003). However, the integrated migrant biomass in the Bransfield Strait was low (192.0 $\mathrm{mg} \mathrm{C} \mathrm{m}^{-2}$ ), compared with previous studies in the area (Voronina et al. 1994; Hernández-León et al. 2000), and was within the lower range (20-5200 $\mathrm{mg} \mathrm{C} \mathrm{m}^{-2}$ ) of values found in Antarctica (Boysen-Ennen et al. 1991; Robins et al. 1995; Ward et al. 1995). The carbon flux due to migrant fauna respiration below 200-m depth $\left(10.2 \mu \mathrm{g} \mathrm{C} \mathrm{m}^{-2}\right.$ day $\left.^{-1}\right)$ represented less than $0.01 \%$ of the averaged primary production measured in the area (2854.5 $\mathrm{mg} \mathrm{C} \mathrm{m}^{-2}$ day $^{-1}$; Agawin, unpubl. data). At the time of our sampling, Khim et al. (2007) were conducting a year-long study to determine carbon fluxes to depths of 960 and $1860 \mathrm{~m}$ in the Bransfield Strait. Most sediment particles (60-73\%) were of lithogenic origin, followed by biogenic silica $(20 \%)$ and organic carbon (3-5\%). The organic carbon flux was similar at 960- and 1860-m depths $\left(54.98\right.$ and $54.49 \mathrm{mg} \mathrm{C} \mathrm{m}^{-2}$ day $^{-1}$, respectively). The authors suggested that this carbon was first coming from the diatom spring bloom (gravitational flux), and, later in summer, from zooplankton faecal pellets (active flux). In this sense, Anadón et al. (2002) observed summer carbon fluxes in the region ranging from 160 to $800 \mathrm{mg} \mathrm{C} \mathrm{m}^{-2}$ day $^{-1}$ at depths of $60-65 \mathrm{~m}$. They calculated an average export flux from the euphotic zone of $294 \pm 89 \mathrm{mg} \mathrm{C} \mathrm{m}^{-2}$ day $^{-1}$, which represented $25.6 \%$ of the primary production (Varela et al. 2002), and suggested that the Bransfield Strait played an important role as a carbon sink area. On the other hand, Ebersbach \& Trull (2008) observed export fluxes due to faecal pellets to be $50-60 \mathrm{mg} \mathrm{C} \mathrm{m}^{-2} \mathrm{~d}^{-1}$ at $100-\mathrm{m}$ depth. They concluded that the majority of export flux was processed through the heterotrophic food web, and was not a direct export of phytoplankton detritus. However, if that was the case in the Bransfield Strait, carbon fluxes would be high during autumn and early winter, when the biomass of copepods peaks. Instead, Khim et al. (2007) observed that more than $99 \%$ of the carbon flux for the year occurred between December and February. The extraordinarily minimal fluxes recorded during the rest of the year suggest important carbon recycling processes in the absence of phytoplankton blooms. Nevertheless, Serret et al. (2001) suggested that seasonal production and respiration uncoupling in the Bransfield Strait would increase the role of hydrodynamics (i.e., advection) in the trophic control of carbon export. Further research during the austral autumn and winter is needed to reveal the importance of microplankton, both as grazers and as prey, if we seek to assess the changes in carbon transport to the deep ocean through the year.

\section{Acknowledgements}

We thank the crew of the RV BIO Hespérides, the technicians of the Unidad de Tecnología Marina (CSIC) and the participants of the ESEPAC 2000 cruise for their support at sea, especially S. Agustí for inviting us to participate in the ESEPAC project (ANT97-0273). We are indebted to N. Agawin for kindly supplying primary production values obtained during the cruise, and X. Morán and I.A. Catalán for providing additional data. This work was undertaken while L. Yebra was at the Biological Oceanography Laboratory of the Universidad de Las Palmas de Gran Canaria, supported by grants from the Spanish Science and Education Ministry (MAR97-1036) and the University of Las Palmas de Gran Canaria. Completion of this work was funded by the European Social Fund (I3P programme, CSIC). 


\section{References}

Agustí S., Satta M.P. \& Mura M.P. 2004. Summer community respiration and pelagic metabolism in upper surface Antarctic waters. Aquatic Microbial Ecology 35, 197-205.

Alcaraz M., Saiz E., Fernández J.A., Trepat I., Figueiras F., Calbet A. \& Bautista B. 1998. Antarctic zooplankton metabolism: carbon requirements and ammonium excretion of salps and crustacean zooplankton in the vicinity of the Bransfield Strait during January 1994. Journal of Marine Systems 17, 347-359.

Anadón R., Álvarez-Marques F., Fernández E., Varela M., Zapata M., Gasol J.M. \& Vaque D. 2002. Vertical biogenic particle flux during austral summer in the Antarctic Peninsula area. Deep-Sea Research Part II 49, 883-901.

Arístegui J., Montero M.F., Ballesteros S., Basterretxea G. \& vanLenning K. 1996. Planktonic primary production and microbial respiration measured by $\mathrm{C}-14$ assimilation and dissolved oxygen changes in coastal waters of the Antarctic Peninsula during austral summer: implications for carbon flux studies. Marine Ecology Progress Series 132, 191-201.

Atkinson A. 1996. Subantarctic copepods in an oceanic, low chlorophyll environment: ciliate predation, food selectivity and impact on prey populations. Marine Ecology Progress Series 130, 85-96.

Atkinson A. 1998. Life cycle strategies of epipelagic copepods in the Southern Ocean. Journal of Marine Systems 15, 289-311.

Atkinson A., Schnack-Schiel S.B., Ward P. \& Marin V. 1997. Regional differences in the life cycle of Calanoides acutus (Copepoda: Calanoida) within the Atlantic sector of the Southern Ocean. Marine Ecology Progress Series 150, 99-111.

Atkinson A. \& Shreeve R.S. 1995. Response of the copepod community to a spring bloom in the Bellingshausen Sea. Deep-Sea Research Part II 42, 1291-311.

Atkinson A. \& Snyder R. 1997. Krill-copepod interactions at South Georgia, Antarctica, I. Omnivory by Euphausia superba. Marine Ecology Progress Series 160, 63-76.

Atkinson A., Ward P., Hill A., Brierley A.S. \& Cripps G.C. 1999. Krill-copepod interactions at South Georgia, Antarctica, II. Euphausia superba as a major control on copepod abundance. Marine Ecology Progress Series 176, 63-79.

Atkinson A., Ward P. \& Murphy E.J. 1996. Diel periodicity of Subantarctic copepods: relationships between vertical migration, gut fullness and gut evacuation rate. Journal of Plankton Research 18, 1387-405.

Båmstedt U. 2000. A new method to estimate respiration rate of biological material based on the reduction of tetrazolium violet. Journal of Experimental Marine Biology and Ecology 251, 239-263.

Basterretxea G. \& Arístegui J. 1999. Phytoplankton biomass and production during late austral spring (1991) and summer (1993) in the Bransfield Strait. Polar Biology 21, $11-22$.
Bergeron J.P., Alayse-Danet A.M. \& Razouls C. 1985. Metabolic adaptations of Antarctic mesozooplanktonic systems to the phytoplankton standing crop in late austral summer. In J.S. Gray \& M.E. Christiansen (eds.): Marine biology of polar regions and the effect of stress on marine organisms. Pp. 157-166. Chichester: Wiley.

Boysen-Ennen E., Hagen W., Hubold G. \& Piatkowski U. 1991. Zooplankton biomass in the ice-covered Weddell Sea, Antarctica. Marine Biology 111, 227-235.

Cabal J.A., Álvarez-Marques F., Acuña J.L., Quevedo M., Gonzalez-Quiros R., Huskin I., Fernández D., del Valle C.R. \& Anadón R. 2002. Mesozooplankton distribution and grazing during the productive season in the northwest Antarctic Peninsula (FRUELA cruises). Deep-Sea Research Part II 49, 869-882.

Calbet A., Alcaraz M., Atienza D., Broglio E. \& Vaque D. 2005. Zooplankton biomass distribution patterns along the western Antarctic Peninsula (December 2002). Journal of Plankton Research 27, 1195-1203.

Catalán I.A., Morales-Nin B., Company J.B., Rotllant G., Palomera I. \& Emelianov M. 2008. Environmental influences on zooplankton and micronekton distribution in the Bransfield Strait and adjacent waters. Polar Biology 31, 691-707.

Conover R.J. \& Huntley M. 1991. Copepods in ice-covered seas. Distribution, adaptations to seasonally limited food, metabolism, growth pattern and life cycle strategies in polar seas. Journal of Marine Systems 2, 1-41.

Drits A.V., Pasternak A.F. \& Kosobokova K.N. 1993. Feeding, metabolism and body-composition of the Antarctic copepod Calanus propinquus Brady with special reference to its life-cycle. Polar Biology 13, 13-21.

Ebersbach F. \& Trull T.W. 2008. Sinking particle properties from polyacrylamide gels during the KErguelen Ocean and Plateau compared Study (KEOPS): zooplankton control of carbon export in an area of persistent natural iron inputs in the Southern Ocean. Limnology and Oceanography 53, 212-224.

Froneman P.W., Pakhomov E.A., Perissinotto R. \& McQuaid C.D. 1996. Role of microplankton in the diet and daily ration of Antarctic zooplankton species during austral summer. Marine Ecology Progress Series 143, 15-23.

Gómez M., Torres S. \& Hernández-León S. 1996. Modification of the electron transport system (ETS) method for routine measurements of respiratory rates of zooplankton. South African Journal of Marine Science 17, 15-20.

Graneli E., Graneli W., Rabbani M.M., Daugbjerg N., Fransz G., Cuzinroudy J. \& Alder V.A. 1993. The influence of copepod and krill grazing on the species composition of phytoplankton communities from the Scotia-Weddell Sea-an experimental approach. Polar Biology 13, 201-213.

Guerra C. 2006. Growth rate determination in larval krill (Euphausia superba Dana) during Antarctic autumn in the Lazarev Sea. A methodology comparison. Master's thesis, University of Bremen. 
Hernández-León S., Almeida C., Portillo-Hahnefeld A., Gómez M. \& Montero I. 2000. Biomass and potential feeding, respiration and growth of zooplankton in the Bransfield Strait (Antarctic Peninsula) during austral summer. Polar Biology 23, 679-690.

Hernández-León S., Almeida C., Portillo-Hahnefeld A., Gómez M., Rodriguez J.M. \& Arístegui J. 2001. Zooplankton biomass and indices of feeding and metabolism in relation to an upwelling filament off northwest Africa. Journal of Marine Research 60, 327-346.

Hernández-León S., Almeida C., Portillo-Hahnefeld A., Gómez M., Rodriguez J.M. \& Arístegui J. 2002. Zooplankton biomass and indices of feeding and metabolism in relation to an upwelling filament off northwest Africa. Journal of Marine Research 60, 327-346.

Hernández-León S. \& Gómez M. 1996. Factors affecting the Respiration/ETS ratio in marine zooplankton. Journal of Plankton Research 18, 239-255.

Hernández-León S. \& Montero I. 2006. Zooplankton biomass estimated from digitalized images in Antarctic waters: A calibration exercise. Journal of Geophysical Research-Oceans 111, C05S03.

Hernández-León S., Portillo-Hahnefeld A., Almeida C., Bécognée P. \& Moreno I. 2001. Diel feeding behaviour of krill in the Gerlache Strait, Antarctica. Marine Ecology Progress Series 223, 235-242.

Hernández-León S., Torres S., Gómez M., Montero I. \& Almeida C. 1999. Biomass and metabolism of zooplankton in the Bransfield Strait (Antarctic Peninsula) during austral spring. Polar Biology 21, 214-219.

Hosie G.W. 1994. The macrozooplankton communities in the Prydz Bay region, Antarctica. In S. El-Sayed (ed.): Southern Ocean ecology. The BIOMASS perspective. Pp. 98-123. London: Cambridge University Press.

Huntley M.E., Brinton E., Lopez M.D.G., Townsend A. \& Nordhausen W. 1990. RACER: fine-scale and mesoscale zooplankton studies during the spring bloom, 1989. Antarctic Journal of the United States 25, 157-159.

Ikeda T. 1985. Metabolic rates of epipelagic marine zooplankton as a function of body-mass and temperature. Marine Biology 85, 1-11.

Ikeda T. \& Motoda S. 1978. Estimated zooplankton production and their ammonia excretion in Kuroshio and adjacent seas. Fishery Bulletin 76, 357-367.

Ikeda T., Torres J.J., Hernandez-Leon S. \& Geiger S.P. 2000. Metabolism. In R.P. Harris et al. (eds.): ICES zooplankton methodology manual. Pp. 455-532. London: Academic Press.

Jacques G. \& Panouse M. 1991. Biomass and composition of size fractionated phytoplankton in the Weddell-Scotia confluence area. Polar Biology 11, 315-328.

Khim B.K., Kim D., Shin H.C. \& Kim D.Y. 2007. Particle fluxes and delta N-15 variation of sinking particles in the central Bransfield Strait (Antarctica). Geosciences Journal 11, 201-209.

King A. \& LaCasella E.L. 2003. Seasonal variations in abundance, diel vertical migration, and population structure of Metridia gerlachei at Port Foster, Deception
Island, Antarctica. Deep-Sea Research Part II 50, 1753-1763.

Lancraft T.M., Hopkins T.L., Torres J.J. \& Donnelly J. 1991. Oceanic micronektonic macrozooplanktonic community structure and feeding in ice covered antarctic waters during the winter (AMERIEZ 1988). Polar Biology 11, 157-167.

Lancraft T.M., Relsenbichler K.R., Robison B.H., Hopkins T.L. \& Torres J.J. 2004. A krill-dominated micronekton and macrozooplankton community in Croker Passage, Antarctica with an estimate of fish predation. Deep-Sea Research Part II 51, 2247-2260.

Lancraft T.M., Torres J.J. \& Hopkins T.L. 1989. Micronekton and macrozooplankton in the open waters near Antarctic ice edge zones (AMERIEZ-1983 and AMERIEZ-1986). Polar Biology 9, 225-233.

Lopez M.D.G. \& Huntley M.E. 1995. Feeding and diel vertical migration cycles of Metridia gerlachei (Giesbrecht) in coastal waters of the Antarctic Peninsula. Polar Biology 15, 21-30.

Lowry P.H., Rosenbrough N.J., Farr A.L. \& Randall R.J. 1951. Protein measurement with a Folin phenol reagent. Journal of Biology and Chemistry 193, 265-275.

Morán X.A.G., Gasol J.M., Pedros-Alio C. \& Estrada M. 2001. Dissolved and particulate primary production and bacterial production in offshore Antarctic waters during austral summer: coupled or uncoupled? Marine Ecology Progress Series 222, 25-39.

Morán X.A.G., Sebastian M., Pedros-Alio C. \& Estrada M. 2006. Response of Southern Ocean phytoplankton and bacterioplankton production to short-term experimental warming. Limnology and Oceanography 51, 1791-1800.

Murray A.W.A., Watkins J.L. \& Bone D.G. 1995. A biological acoustic survey in the marginal ice-edge zone of the Bellingshausen Sea. Deep-Sea Research Part II 42, 1159-1175.

Omori M. \& Ikeda T. 1984. Methods in marine zooplankton ecology. New York: John Wiley and Sons.

Packard T.T. 1971. The measurement of respiratory electron transport activity in marine phytoplankton. Journal of Marine Research 29, 235-244.

Packard T.T., Devol A.H. \& King F.D. 1975. Effect of temperature on the respiratory electron transport system in marine plankton. Deep-Sea Research 22, 237-249.

Pakhomov E.A., Perissinotto R. \& McQuaid C.D. 1994. Comparative structure of the macrozooplankton/ micronecton communities of the subtropical and Antarctic Polar fronts. Marine Ecology Progress Series 111, 155-169.

Pakhomov E.A., Perissinoto R. \& McQuaid C.D. 1996. Prey composition and daily rations of myctophid fishes in the Southern Ocean. Marine Ecology Progress Series 134, 1-14.

Pakhomov E.A., Perissinotto R., McQuaid C.D. \& Froneman P.W. 2000. Zooplankton structure and grazing in the Atlantic sector of the Southern Ocean in late austral summer 1993. Part 1. Ecological zonation. Deep-Sea Research Part I 47, 1663-1686. 
Park C. \& Wormuth J.H. 1993. Distribution of Antarctic zooplankton around Elephant-Island during the austral summers of 1988, 1989, and 1990. Polar Biology 13, 215-225.

Pasternak A.F. \& Schnack-Schiel S.B. 2001. Feeding patterns of dominant Antarctic copepods: an interplay of diapause, selectivity, and availability of food. Hydrobiologia 453, 25-36.

Perissinotto R., Gurney L. \& Pakhomov E.A. 2000. Contribution of heterotrophic material to diet and energy budget of Antarctic krill, Euphausia superba. Marine Biology 136, 129-135.

Postel L., Fock H. \& Hagen W. 2000. Biomass and abundance. In R.P. Harris et al. (eds.): ICES zooplankton methodology manual. Pp. 83-192. London: Academic Press.

Price H.J., Boyd K.R. \& Boyd C.M. 1988. Omnivorous feeding behaviour of the Antarctic krill Euphausia superba. Marine Biology 97, 67-77.

Robins D.B., Harris R.P., Bedo A.W., Fernandez E., Fileman T.W., Harbour D.S. \& Head R.N. 1995. The relationship between suspended particulate material, phytoplankton and zooplankton duirng the retreat of the marginal ice zone in the Bellingshausen Sea. Deep-Sea Research Part II 42, 1137-1158.

Rutter W.J. 1967. Protein determinations in embryos. In F.H. Wilt 8 N.K. Wessels (eds.): Methods in developmental biology. Pp. 671-684. New York: Academic Press.

Schalk P.H. 1990. Biological activity in the Antarctic zooplankton community. Polar Biology 10, 405-411.

Schnack-Schiel S.B. \& Hagen W. 1994. Life cycle strategies and seasonal variations in distribution and population structure of four dominant calanoid copepod species in the eastern Weddell Sea, Antarctica. Journal of Plankton Research 16, 1543-1566.

Schnack-Schiel S.B. \& Hagen W. 1995. Life-cycle strategies of Calanoides acutus, Calanus propinquus, and Metridia gerlachei (Copepoda: Calanoida) in the eastern Weddell Sea, Antarctica. ICES Journal of Marine Science 52, 541-548.

Schnack-Schiel S.B. \& Mújica A. 1994. The zooplankton of the Antarctic Peninsula region. In S.Z. El-Sayed (ed.): Southern Ocean ecology. The BIOMASS perspective. Pp. 79-92. London: Cambridge University Press.

Schneider G. 1989. Carbon and nitrogen content of marine zooplankton dry material: a short review. Plankton Newsletter 12, 41-44.

Serret P., Fernández E., Anadón R. \& Varela M. 2001. Journal of Plankton Research 23, 1345-1360.

Sturz A.A., Gray S.C., Dykes K., King A. \& Radtke J. 2003. Seasonal changes of dissolved nutrients within and around Port Foster Deception Island, Antarctica. Deep-Sea Research Part II 50, 1685-1705.

Tucker M.J. \& Burton H.R. 1990. Seasonal and spatial variations in the zooplankton community of an eastern Antarctic coastal location. Polar Biology 10, 571-579.
Varela M., Fernandez E. \& Serret P. 2002. Size-fractionated phytoplankton biomass and primary production in the Gerlache and south Bransfield Straits (Antarctic Peninsula) in austral summer 1995-1996. Deep-Sea Research Part II 49, 749-768.

Voronina N.M., Kosobokova K.N. \& Pakhomov E.A. 1994. Composition and biomass of summer metazoan plankton in the 0-200 m layer of the Atlantic sector of the Antarctic. Polar Biology 14, 91-95.

Ward P., Atkinson A., Murray A.W.A., Wood A.G., Williams R. \& Poulet S.A. 1995. The summer zoplankton community at South Georgia: biomass, vertical migration and grazing. Polar Biology 15, 195-208.

Ward P., Atkinson A., Schnack-Schiel S.B. \& Murray A.W.A. 1997. Regional variation in the life cycle of Rhincalanus gigas (Copepoda: Calanoida) in the Atlantic sector of the Southern Ocean-re-examination of existing data (1928 to 1993). Marine Ecology Progress Series 157, 261-275.

Ward P., Grant S., Brandon M., Siegel V., Sushin V., Loeb V. \& Griffiths H. 2004. Mesozooplankton community structure in the Scotia Sea during the CCAMLR 2000 Survey: January-February 2000. Deep-Sea Research Part II 51, 1351-1367.

Weeks A.R., Griffiths G., Roe H., Moore G., Robinson I.S., Atkinson A. \& Shreeve R. 1995. The distribution of acoustic backscatter from zooplankton compared with physical structure, phytoplankton and radiance during the spring bloom in the Bellinghausen Sea. Deep-Sea Research Part II 42, 997-1019.

Wickham S.A. \& Berninger U.G. 2007. Krill larvae, copepods and the microbial food web: interactions during the Antarctic fall. Aquatic Microbial Ecology 46, 1-13.

Yebra L., Almeida C. \& Hernández-León S. 2005. Vertical distribution of zooplankton and active flux across an anticyclonic eddy in the Canary Island waters. Deep-Sea Research Part I 52, 69-83.

Yebra L., Harris R.P. \& Smith T. 2005. Comparison of five methods for estimating growth of Calanus helgolandicus later developmental stages (CV-CVI). Marine Biology 147, 1367-1375.

Yebra L. \& Hernández-León S. 2004. Aminoacyl-tRNA synthetases activity as a growth index in zooplankton. Journal of Plankton Research 26, 351-356.

Yebra L., Hirst A.G. \& Hernández-León S. 2006. Assessment of Calanus finmarchicus growth and dormancy using the aminoacyl-tRNA synthetases method. Journal of Plankton Research 28, 1191-1198.

Zhou M., Niller P.P., Zhu Y.W. \& Dorland R.D. 2006. The western boundary current in the Bransfield Strait, Antarctica. Deep-Sea Research Part I 53, 1244-1252.

Zhou M., Nordhausen W. \& Huntley M. 1994. ADCP measurements of the distribution and abundance of euphausiids near the Antarctic Peninsula in winter. Deep-Sea Research Part I 41, 1425-1445. 